\title{
Entrepreneurial Activity in Post-Socialist Countries: Methodology and Research Limitations
}

\author{
Alexander Chepurenko \\ Professor, Faculty of Social Sciences; and Head, Department of Economic Sociology, achepurenko@hse.ru \\ National Research University Higher School of Economics, 11, Myasnitskaya str., Moscow 101000, Russian Federation.
}

\begin{abstract}
$\mathrm{T}$ The subject of this article is the entrepreneurial activity of the population residing in the post-socialist countries of Central and Eastern Europe (CEE), and its goal is to identify different types of ecosystems of entrepreneurship in these countries by means of analyzing entrepreneurial activity in various countries/groups of countries considered in the context of their societal and economic development. Empirically this article is based upon data from the Global Entrepreneurship Monitor (GEM). On the basis of an analysis of the strengths and weaknesses of existing approaches in the relevant literature to the taxonomy of business ecosystems, using a set of key country-level indicators of the GEM for 2011, this article proposes a taxonomy for entrepreneurship ecosystems
\end{abstract}

Abstract

\section{Keywords:}

entrepreneurship ecosystem;

entrepreneurial activity;

Central and Eastern Europe;

entrepreneurship theory. based on two «axes» - the quality of entrepreneurial activity (high, average, below average) and the state of the entrepreneurial framework conditions in the respective countries (favorable, average, below average). The result is a clustering of CEE countries' entrepreneurship ecosystems, where the worst cluster consists solely of Bosnia and Herzegovina, and the best contains the Czech Republic. Russia belongs to a cluster with mid-level indicators along both axes. The results might be used to implement a more focused policy promoting entrepreneurship and support for small businesses, which must move away from generalized schemes towards concrete policy concepts taking into account the resources and limitations of each of the selected types of entrepreneurship ecosystems.
Citation: Chepurenko A. (2017) Entrepreneurial Activity in Post-Socialist Countries: Methodology and Research Limitations. Foresight and STI Governance, vol. 11, no 3, pp. 11-24. DOI: 10.17323/2500-2597.2017.3.11.24 


\section{The emergence of entrepreneurship during the early stages of systemic transformation}

One of the major aims of the process of systemic transformation in the former Socialist countries in the late 1980s - early 1990s was the promotion of private entrepreneurship as a key tool for transitioning to a market economy [Kornai, 1992; Dallago, 1997; Blanchard, 1998; McMillan, Woodruff, 2002; et al.]. The international organizations that provided consulting and financial support for designing and establishing new institutions, along with the majority of national experts in Central and Eastern European (CEE) countries and the former USSR republics, assumed that entrepreneurship would emerge and become embedded in more or less the same forms, relying on similar legal principles and institutional prerequisites. All these factors were supposed to emerge along with the establishment of suitable socioeconomic conditions [Sachs, 1996; Gros, Steinherr, 2004] and the transfer of international experience, primarily that of the US and the EU.

The challenges entrepreneurs in the post-socialist countries faced during the initial stage of systemic transformation in most cases were common among them all [Kornai, 1992; Sachs, 1996; Johnson et al., 2000; Aidis, 2005a, 2005b]. However, by the mid to late 1990s, it became clear that these countries had split into two groups: transitional economies (i.e., those relatively successful in creating the conditions and prerequisites for the emergence of an entrepreneurial ecosystem) [Smallbone, Welter, 2002; et al.], and those that lagged in this process. The different levels of performance of said entrepreneurship ecosystems were mostly determined by their previous development experiences (path dependence).

It turned out that the average level of entrepreneurial dynamics in these countries was lower than expected at the early stage of the systemic transformation [Scase, 1997]. Moreover, experts noted that in most of these economies, privatization did not lead to the emergence of increased opportunities for new "Schumpeterian" entrepreneurship based on the formerly public assets [Kontovorich, 1999; Black et al., 2000; Earle, Sakova, 2000; Chilosi, 2001; Puffer, McCarthy, 2001; Manolova et al., 2008; Hashi, Krasniqi, 2011]. Furthermore, in many countries privatization in effect amounted to assets being seized by the former "nomenklatura" or by large multinational corporations supported by the new political elite. In other words, the phenomenon of so-called "predatory entrepreneurship" became a prominent feature of the initial stage of systemic transformation [Feige, 1997; Scase, 2003; Spicer et al., 2000].

Contrary to the large companies that emerged due to a "top-down" redistribution of formerly public assets between political entrepreneurs making use of their informal connections with decision-makers in many CIS countries [Boycko et al., 1997; Rehn, Taalas, 2004], the "bottom-up" spontaneous entrepreneurship, mostly represented by micro- and small businesses or solo entrepreneurs, had to rent the assets required to successfully operate their businesses from the state.

By the second half of the 1990s, it was generally accepted that countries transitioning to the new socioeconomic system were not homogeneous. Experts began to differentiate between the former Soviet republics, on the one hand, and the CEE and Baltic countries, on the other. After several of the latter were integrated into the EU, this division was accepted in the literature. A comparative analysis of the institutional environments and specific features of entrepreneurship in both groups of countries focused primarily on the following aspects (Table 1).

\section{From a common past to a different present}

By the early 2000s it became evident in the literature that the CEE and Baltic countries had achieved notable progress in their systemic transition to an entrepreneurial economy compared with the former republics - the members of the Commonwealth of Independent States (CIS) [Smallbone, Welter, 2002] ${ }^{1}$. Even in historically and geographically close countries, a basic indicator such as Total Early-Stage Entrepreneurial Activity (TEA) varies significantly (Figure 1).

Notably, the average TEA in post-socialist countries is higher than in the "older" EU member states. A possible explanation is the base effect: in such new market economies, market entry barriers and competition remain low, therefore it is easier to establish and run imitative (as opposed to innovative) businesses. It should be kept in mind that a significant part of entrepreneurial activity in post-socialist countries still is necessity-driven [Earle, Sakova, 2001] (Figure 2).

Compared with other EU economies covered by the GEM, the entrepreneurs in post-socialist countries have more modest ambitions regarding growth and new markets, preferring to do business on markets where they already are present; they do not try attract new groups of customers and consumers. However, there are certain differences in this regard as well (Figure 3).

\footnotetext{
More localized (geographically or in terms of foreign policy) clusters of post-social countries are also suggested, such as the Visegrad Group or the Black Sea Basin countries (including non-socialist Greece and Turkey). Some researchers also insist upon the need to view former the Yugoslav republics separately, given that Yugoslavia had market socialism as opposed to the planned, state-run economy [Szerb, Trumbull, 2015].
} 


\section{Table 1. Varying conditions for the development of entrepreneurship in CEE countries} and the former Soviet republics in the 1990s

\begin{tabular}{|c|c|c|}
\hline Factor & CEE countries & CIS countries \\
\hline \multirow{9}{*}{ Environment } & Association with Europe and EU countries & Dominance of old Soviet networks \\
\hline & $\begin{array}{l}\text { Western-oriented development, free market and } \\
\text { democracy as their declared goals }\end{array}$ & Mafia-style capitalist development, "crony capitalism" \\
\hline & Regulatory system of the EU (importing institutions) & $\begin{array}{l}\text { Regulatory system, taking into account best practices and the } \\
\text { countries' own developments (diffused institutes) }\end{array}$ \\
\hline & Stable and transparent institutions & No transparency, frequently changing institutions \\
\hline & $\begin{array}{l}\text { During socialist period, small and limited } \\
\text { private business culture survived }\end{array}$ & $\begin{array}{l}\text { During socialist period, private business culture was } \\
\text { completely eliminated }\end{array}$ \\
\hline & Memory of private businesses & No memory of private businesses \\
\hline & $\begin{array}{l}\text { Communism collapsed and resulted in a new political } \\
\text { elite }\end{array}$ & $\begin{array}{l}\text { Communism collapsed with only some change to the political } \\
\text { elite }\end{array}$ \\
\hline & Lack of financing & Lack of financing \\
\hline & Lower levels of corruption & Higher levels of corruption \\
\hline \multirow{2}{*}{ Role of the state } & Invisible hand model governing the market & Grabbing hand model: model of state distribution \\
\hline & Culture of cooperation and support & Culture of surveillance and inspections \\
\hline \multirow{6}{*}{$\begin{array}{l}\text { Business } \\
\text { owners' } \\
\text { characteristics }\end{array}$} & $\begin{array}{l}\text { Private businesses dominate economic activity, } \\
\text { stability is the main goal }\end{array}$ & $\begin{array}{l}\text { Business development focused on the 'big strike' or getting } \\
\text { rich quickly; coping with unstable market conditions }\end{array}$ \\
\hline & $\begin{array}{l}\text { Private businesses dominate economic activity, } \\
\text { stability is the main goal }\end{array}$ & Generic business activities \\
\hline & Diversified business sectors & Business activities primarily engaged in trade \\
\hline & Business development seen as a gradual process & $\begin{array}{l}\text { Part-time businesses in combination with employment in the } \\
\text { state sector }\end{array}$ \\
\hline & Individual businesses are the dominant form & Partnerships for business protection and survival predominate \\
\hline & Businesses function as part of an official economy & Businesses function in both official and informal economies \\
\hline
\end{tabular}

In some countries, the product-innovation TEA is more than twice as high as in some others: $17 \%$ in Slovenia vs. only $6 \%$ in Hungary. Regarding technological innovations the gap is even wider, all the way to sevenfold: $28 \%$ in the Czech Republic vs. only $3 \%$ in the neighboring Poland (both being fellow members of the Visegrad Group).

Therefore, in the academic literature on entrepreneurship in post-socialist countries, a gradual shift towards factors that might explain the above differences occurred. By the early 2000s, three relevant theories emerged in the literature. The first links the aforementioned diversity to the variability of initial institutional and societal matrices, which do not help (or even hinder) the development of entrepreneurship [Aidis, 2005b; Ovaska, Sobel, 2005; van der Zwan, 2011]. Authors in the second group concentrate on microlevel factors such as the individual characteristics of entrepreneurs in specific countries [McMillan, Woodruff, 2002; Cieslik, van Stel, 2012; Lafuente, Vaillant, 2013]. They stressed that there were not solely different attitudes towards entrepreneurship in society, but also various types of entrepreneurs with different motivations, goals and objectives, values, etc., prevailing in different transitional societies.

Finally, researchers in the third group insist on the need to take into account both institutional and specific individual features of the entrepreneurs [Estrin et al., 2006; Hashi, Krasniqi, 2011]. Following William Baumol [Baumol, 1990], they stress the differences between productive, non-productive, and destructive entrepreneurship [Kihlgren, 2003; Sauka, Welter, 2007], which combined with various

\section{Figure 1. Share of early-stage entrepreneurs in the working population of EU countries(\%)}

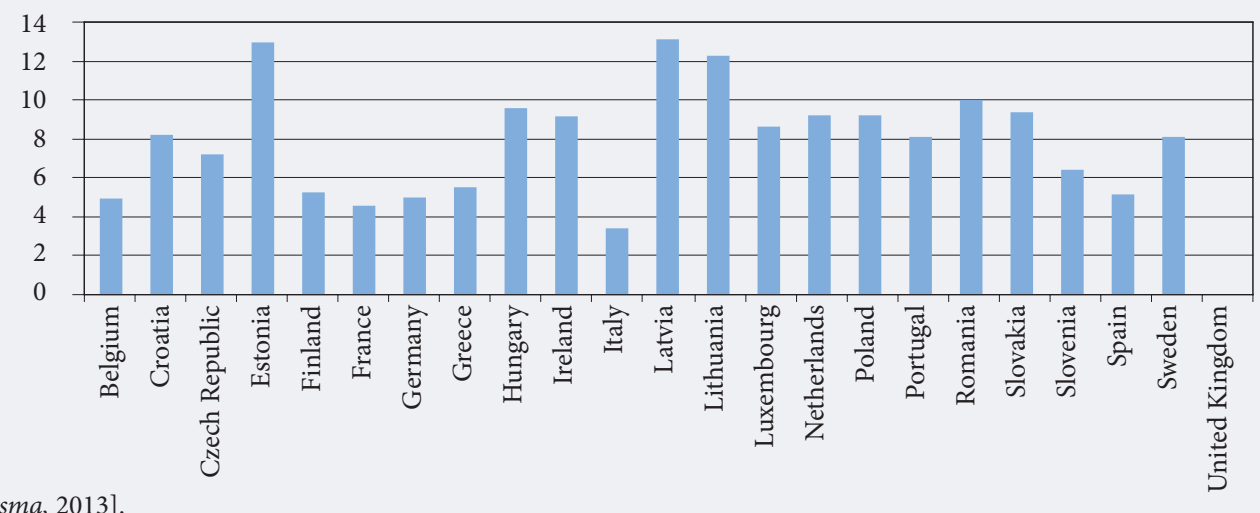


Figure 2. Shares of opportunity- and necessitydriven early-stage entrepreneurs among the economically active adult population of postsocialist European countries: 2001-2011 (\%)

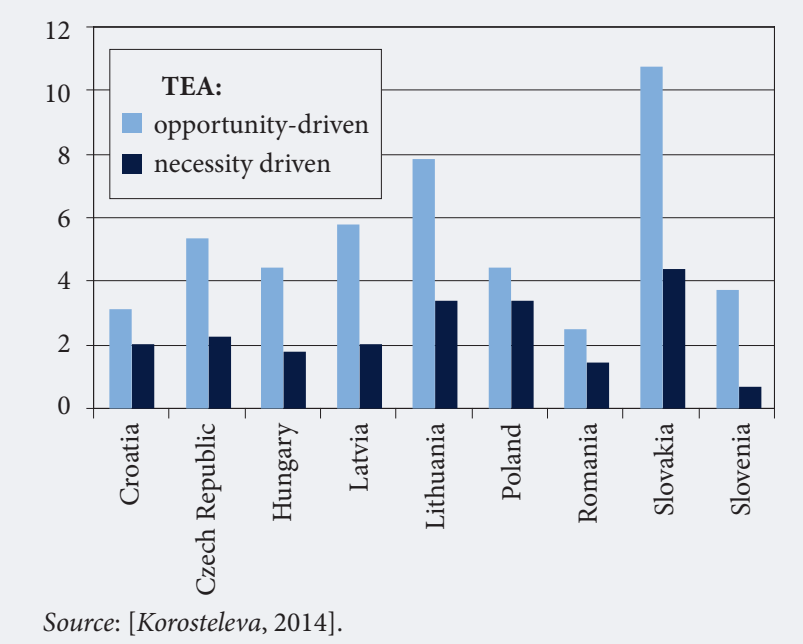

Figure 3. Structure of early-stage

entrepreneurship in post-socialist countries

by innovation type: average values for $2001-2011(\%)$

\begin{abstract}
institutional barriers creates different business habitats. Looking through such a lens, it becomes possible to identify different as well as some completely unique entrepreneurial ecosystems, comprising a small number of innovative companies with high growth potential and a mass of non-productive actors such as microenterprises, the self-employed (including those engaged in informal and shadow sectors of the economy), and businesses whose main resource is political rent (e.g., revenues generated through corruption, etc.) or even criminal violence [Smallbone, Welter, 2002; Volkov, 2012] (see Table 2). Not only do formal institutions whose development is monitored by international organizations and reflected in special indices (such as Doing Business ${ }^{2}$ etc.) play a role, informal ones do as well. These were noted by Saul Estrin and Tomasz Mickiewicz [Estrin, Mickiewicz, 2010] who among other things analyzed various attitudes, perceptions [Chepurenko, 2008], and social norms including trust [Raiser et al., 2003; Welter et. al., 2005].

Accession to the EU in 2004 and the rapid institutional development of eight CEE and Baltic countries (and, subsequently, three Balkan nations) resulted in increasingly different conditions for entrepreneurship there and in other transitional economies. This gap was due to the implementation of the framework principles of and approaches to providing support to entrepreneurship in the new EU member states, which permitted international organizations, to distinguish them from economies that do not meet the EU's requirements for business conditions and the development of the entrepreneurial environment. It is assumed by international organizations that the new EU members have completed their systemic transition [Kornai, 2006; Gros, Steinherr, 2004], while other countries are still moving towards that goal. In effect, geopolitical factors have become the criteria for classifying post-socialist countries.
\end{abstract}

\title{
Approaches to classifying entrepreneurial ecosystems: different approaches in the literature
}

An analysis of the framework conditions and entrepreneurial activities on the basis of Global Entrepreneurship Monitoring (GEM) data and various indices used by international organizations gives reason for doubting the relevance of such a geopolitically based approach to the typologization

\section{Table 2. Entrepreneur types based on motivation and source of revenues}

\begin{tabular}{|c|c|c|c|}
\hline & \multicolumn{3}{|c|}{ Entrepreneurship } \\
\hline & Productive & Non-productive & Destructive \\
\hline Necessity-driven & "Shuttles" & "Roofers" & "Raiders" \\
\hline $\begin{array}{l}\text { Opportunity- } \\
\text { driven }\end{array}$ & $\begin{array}{l}\text { Entrepreneurs/companies with high } \\
\text { growth potential ('gazelles') }\end{array}$ & Public and partially public monopolies & "Violent entrepreneurship" \\
\hline
\end{tabular}

Source: [Chepurenko, 2015]. 
Table 3. EFC quality and entrepreneurial activity indicators in post-socialist countries (based on the GEM data for 2011)

\begin{tabular}{|l|c|c|}
\hline \multicolumn{1}{|c|}{ Country } & $\left(\boldsymbol{T E A}_{\text {IDE }}-\boldsymbol{T E A}_{\text {nec }}\right): \boldsymbol{T E A}_{\text {mixed }}$ & $\left(\boldsymbol{B B O}-\boldsymbol{B U S}_{\text {disc }}\right)^{-1.3}$ \\
\hline Bosnia and Herzegovina & -2.329 & -1.3 \\
\hline Croatia & -0.135 & 1.7 \\
\hline Hungary & -0.045 & 2.5 \\
\hline Latvia & 0.728 & 3.8 \\
\hline Lithuania & 0.770 & 1.8 \\
\hline Poland & -2.110 & 1.7 \\
\hline Romania & -0.285 & 0.9 \\
\hline Russia & 0.481 & 2.2 \\
\hline Slovakia & 0.164 & 2.4 \\
\hline Czech Republic & 1.802 & 0.4 \\
\hline Slovenia & 1.065 & \\
\hline Source: $[$ Bosma et al., 2012]. & & \\
\hline
\end{tabular}

of post-socialist countries, at least as regards the ecosystems of entrepreneurship [Chepurenko, 2015; Szerb, Trumbull, 2015]. As Acs et al. said: "Because entrepreneurship researchers have focused on the individual and ignored the context, we have missed at least three important points: (1) that it is the context that regulates who decides to start a new firm; (2) it is the context that regulates what kind of firm they will start; (3) that the context also decides how aggressively the firm will pursue growth and with what outcomes" [Acs et al., 2016, p. 530]. In our opinion, obtaining a deeper and more precise understanding of the nature of entrepreneurship in post-socialist countries [Chepurenko, 2015] requires a deep immersion into the context of the various respective ecosystems, by studying the following areas:

- Context-dependent classification of transitioning societies and economies based upon an analysis of various institutional matrices and empirical data [Aidis et al., 2010a; Chepurenko et al., 2012; Estrin, Mickiewicz, 2010; Obraztsova, Chepurenko, 2010; Szerb, Trumbull, 2015; Welter, 2005; Welter, Smallbone, 2011b; et al.];

- An analysis of the effects of various types of interactions between networks, formal and informal institutions, and their impact on entrepreneurial behavior [Batjargal, 2006; Commander, Tolstopiatenko, 1997; Rehn, Taalas, 2004; et al.];

- Studying the variety and heterogeneity of productive, non-productive, and destructive entrepreneurship during a systemic transformation [Rona-Tas, Sagi, 2005; Sauka, Welter, 2007; et al.];

- Identifying and analyzing the role of institutional traps that appear as a result of the import of institutions and best practices; analyzing the evolution of small and medium business development policies [Welter, Smallbone, 2011a].

New theoretical approaches emerging in the scope of institutional theory allow one to critically rethink the development of entrepreneurship in post-socialist countries. Employing a wide range of empirical data available to researchers, they allow one to make quantitative comparisons beyond the scope of official statistics. For example, our study [Chepurenko, 2015] suggests a cluster-based approach to measuring business activity as an extension of the "different transformations" concept (similar to the "different capitalism" models) [Hall, Soskice, 2001]). The diversity of entrepreneurial ecosystems is manifested through the disparity between the so-called entrepreneurial framework conditions (EFC) and the level of entrepreneurial activity in post-socialist countries. This concept does not refer to path dependence, i.e., the state of societies before the beginning of systemic transition alone, but finds classification criteria in the conditions and institutions that have emerged over the course of the systemic transformation process itself. According to the GEM explanatory model, entrepreneurial framework conditions reflecting the socioeconomic context [Welter, 2011] include a set of institutions that affect the quality of the business environment and are measured using 10 indicator groups. The GEM has no integrated EFC indicator, therefore as a substitute for a national-level EFC index, we used an indicator calculated as the difference between the share of nascent business owners and the share of individuals who have shut down a business over the past year among the adult population provided by the GEM APS data. The difference between the number of those persons entering and leaving entrepreneurial activity over the same period of time though it can be due in part to personal circumstances and motives - would still be representative enough to illustrate the entrepreneurs' perceptions of the framework conditions for their activities. As the GEM annual monitoring surveys show, this perception turned out to be decisive for the establishment and liquidation of new firms alike. Thus, the quality of the entrepreneurial framework conditions can be expressed using the following formula: 


\section{Table 4. Distribution of post-socialist economies depending on the quality of entrepreneurial} framework conditions and entrepreneurial potential (2011)

\begin{tabular}{|l|l|l|l|}
\hline & $\left(T E A_{\text {IDE }}-T E A_{\text {nec }}\right): T E A_{\text {mixed }}<0$ & $0<\left(T E A_{\text {IDE }}-T E A_{\text {nec }}\right): T E A_{\text {mixed }}<1$ & $\left(T E A_{\text {IDE }}-T E A_{\text {nec }}\right): T E A_{\text {mixed }}>1$ \\
\hline$\Delta$ of $T E A<0$ & Bosnia and Herzegovina & - & - \\
\hline $0<\Delta$ of $T E A<2$ & Croatia, Poland, Romania & Russia & Slovenia \\
\hline$\Delta$ of $T E A>2$ & Hungary & Latvia, Lithuania, Slovakia & Czech Republic \\
\hline \multicolumn{2}{|l}{ Source: calculated by the author on the basis of materials in [Bosma et al., 2012]. } \\
\hline
\end{tabular}

$$
\triangle o f T E A=\left(B B O-B U S_{\text {disc }}\right),
$$

where:

$B B O$ is the share of nascent entrepreneurs, and

$B U S_{d i s c}$ is the share of people who have discontinued their entrepreneurial activities over the course of the previous year.

The 'quality' of entrepreneurial activity does not solely reflect entrepreneurs' ability to contribute to employment and economic growth in a country. As it is shown [Schillo, Persault, 2016], entrepreneurial intentions not only reflect individuals' willingness to become entrepreneurs, but also certain components of the national business environment. Motivation, its character - driven by opportunity or necessity is one of the parameters governing individual entrepreneurial aspirations, while the structure of that motivation, or the ratio of improvement-driven entrepreneurship (IDE) and necessity-driven activity is an important indicator for the entrepreneurial potential of the population. Numerous empirical studies [Hessels et al., 2008; Shane et al., 2003] demonstrate that various motivations affect goal-setting and the entrepreneurial strategies of newly established and developing firms, i.e., their potential for growth, export, and innovation - differently. Moreover, the GEM methodology [Reynolds et al., 2005] focuses on differences in entrepreneurs' motivation in various countries, and especially on its effect on the socalled U-curve of the correlation between entrepreneurial activity and economic development in various groups of countries [Reynolds et al., 2005]. The difference between prevailing entrepreneurial motivation (IDE or necessity) divided by the share of those motivated by mixed considerations can be used as an indicator of the quality of entrepreneurial activity, i.e.:

where:

$$
\left(T E A_{I D E}-T E A_{n e c}\right): T E A_{\text {mixed }} \text {, }
$$

$T E A_{I D E}$ is the share of improvement-driven early-stage entrepreneurs,

$T E A_{n e c}$ is the share of necessity-driven early-stage entrepreneurs, and

$T E A_{\text {mixed }}$ is the share of early-stage entrepreneurs with mixed motivations correlated with their ambitions for growth and job creation.

$T E A_{\text {mixed }}$ is an important indicator because in certain economies, a large, occasionally even predominant, share of early-stage entrepreneurs are motivated both by necessity and opportunity, so taking into consideration only these two types does not completely cover the motivational structure of nascent businessmen in the relevant national samples.

The GEM data for 2011 (the year with the highest concentration of post-socialist countries in the GEM over the recent period of the project's implementation) allowed [Chepurenko, 2015] to obtain a quite precise picture of the framework conditions and entrepreneurial activity in several countries (Table 3).

Taking into account the entrepreneurial framework conditions and the quality of entrepreneurial potential (presented as two axes), a model for clustering post-social economies by entrepreneurship ecosystem type was built (Table 4).

\section{Table 5. Entrepreneurial ecosystems in post-socialist countries}

\begin{tabular}{|l|l|l|}
\hline \multicolumn{1}{|c|}{ Country } & Quality of entrepreneurial activity & Framework conditions \\
\hline Bosnia and Herzegovina & Low & Poor \\
\hline Poland, Romania, Croatia & Low & Average \\
\hline Hungary & Low & Best \\
\hline Russia & Average & Average \\
\hline Latvia, Lithuania, Slovakia & Average & Best \\
\hline Slovenia & Best & Average \\
\hline Czech Republic & Best & Best \\
\hline \multicolumn{2}{|l|}{ Source: composed by the author on the basis of data in [Bosma et al., 2012]. } \\
\hline
\end{tabular}


$\triangle o f T E A<0$ means that entrepreneurial framework conditions in the relevant country are very poor; $0<\triangle$ of $T E A<2$ means they are satisfactory; and $\triangle O f T E A>2$ implies relatively favorable conditions. The values of $\left(T E A_{I D E}-T E A_{\text {nec }}\right): T E A_{\text {mixed }}<0$ indicate the low quality of entrepreneurship. In countries falling within the range of $0<\left(T E A_{I D E}-T E A_{\text {nec }}\right): T E A_{\text {mixed }}<1$ entrepreneurial activity can be assessed as satisfactory, and those whose values reach the level of $\left(T E A_{I D E}-T E A_{\text {nec }}\right): T E A_{\text {mixed }}>1$ have the best conditions for the development of entrepreneurship. The relevant GEM data allows one to rank entrepreneurial ecosystems of post-socialist countries (Table 5).

Some countries, such as Russia or Hungary, look better than could be expected on the basis of expert assessments of their current economic and political situations; others (e.g., Poland) conversely do not live up to expectations. Nevertheless, the results illustrate our main point: 20 years after the beginning of systemic transformation in European socialist countries and the former Soviet Union, entrepreneurial ecosystems and related conditions are quite different. Among other things this means that specific approaches need to be employed both to analyze the reasons and to make policy recommendations to improve framework conditions for and provide support to entrepreneurship and SMEs in the aforementioned countries. Weak points of our evidence include the limited range of post-socialist economies covered by the GEM project: most of the CIS and Balkan countries do not take part in it at all, while some others only participate in certain rounds, which makes it difficult to obtain dynamic data arrays covering several years. Accordingly, only two groups out of seven include more than one country, which reduces the value of such a classification.

A comparatively novel mechanism for an international comparison of entrepreneurial development was proposed in the scope of the so-called knowledge spill-over theory of entrepreneurship (KSTE): the Global Entrepreneurship Development Index (GEDI). This integrated indicator is calculated on the basis of 31 variables divided into 14 groups, which in turn are subsumed into three sub-indices [Acs, Szerb, 2011]. The authors assume a set of individual and institutional characteristics exists in each country at a particular period of time, which together constitute a national entrepreneurship system (NES):

'... A National System of Entrepreneurship is the dynamic, institutionally embedded interaction between entrepreneurial attitudes, ability, and aspirations by individuals, which drives the allocation of resources through the creation and operation of new ventures' [Acs et al., 2014, p. 479].

The NES concept is systemic due to the fact that the cumulated impact of all the factors it comprises is larger than their sum. Unlike the microlevel (characteristics of, and resources available to, specific entrepreneurs) and mesolevel (networks, trust, etc.) approaches, the NES concept assumes that the development of entrepreneurship is affected by societal and institutional factors. However, this perspective reduces the problem to conditions for establishing and operating new companies, hence it follows that the definition of entrepreneurship reads solely as the process of establishing and managing of new ventures. A less restrictive concept of an entrepreneurial system was put forward by [Autio, Levie, 2015], which describes the relationship between all processes and stages of development through the institutional context, seems to be more appropriate.

Another limitation of the index built in the scope of the NES concept is the sources of data for calculating it. Along with surveys of the economically active adult population and entrepreneurs within the framework of the GEM project, certain variables are borrowed from databases maintained by organizations who use different measurement techniques (statistical, expert-based, etc.), which makes the whole GEDI index highly subjective. In addition, the aggregated sub-indices are not weighted when the overall index is calculated: their arithmetic mean is simply extracted [Acs, Szerb, 2011]. This approach does not take into account the various weights of the same factors when decisions to create a new company or carry on with the business are made in different types of economies. It contradicts, for instance, the NES concept authors' thesis that, high-tech start-ups can play a more important role in countries where large public companies dominate than in economies in which most of the firms are SMEs [Acs et al., 2013]. For the latter group of nations (which includes almost the whole of CEE), the low level of high-tech entrepreneurship seems to be less critical to the quality of business environment than the level of people's education and entrepreneurial skills. Therefore, the value of this indicator for very different economies should be adjusted using a reduced weight coefficient. Consequently, some distortions are embedded in the GEDI methodology by definition.

Nevertheless, a comparison of GEDI values [Szerb, Trumbull, 2015] confirms the economic, societal, and cultural heterogeneity of post-socialist countries, which manifests itself in the different entrepreneurial ecosystems. Most of them match the level of more advanced non-European economies (see Table 6), with widely varying index values (ranging from 57.8 in Estonia to 30.4 in the bottom-ranking Bosnia and Herzegovina) - which makes the inclusion of "post-socialist countries" in a group of their own pointless. The classification suggested by the World Economic Forum (WEF) [WEF, 2015] in a number of cases raises similar doubts. For example, on the basis of per capita GDP figures, Italy and Greece are included in the group of innovative economies in the middle of the ranking, while Brazil (included in the second group of efficiency-driven economies) finds itself among the countries with the least developed entrepreneurship. All in all, such biases make one doubt the relevance of the per capita GDP indicator for typologizing countries and economies in the first place. 


\section{Table 6. Post-socialist countries in the GEDI Ranking (2012)}

\begin{tabular}{|c|c|c|c|c|c|c|c|c|c|}
\hline Ranking & Country & $\begin{array}{l}\text { GDP } \\
\text { (USD) }\end{array}$ & GEDI & \begin{tabular}{|c}
$\begin{array}{c}\text { Development } \\
\text { level }\end{array}$ \\
\end{tabular} & Ranking & Country & $\begin{array}{l}\text { GDP } \\
\text { (USD) }\end{array}$ & GEDI & $\begin{array}{c}\text { Development } \\
\text { level }\end{array}$ \\
\hline 1 & US & 42486 & 79.4 & 3 & 43 & Italy & 27072 & 41.3 & 3 \\
\hline 2 & Denmark & 32582 & 77.1 & 3 & 44 & Barbados & 17564 & 40.7 & 2 \\
\hline 3 & Australia ${ }^{*}$ & 34396 & 74.3 & 3 & 45 & Montenegro ${ }^{* *}$ & 10469 & 40.7 & 2 \\
\hline 4 & Sweden & 35170 & 71.5 & 3 & 46 & South Africa & 9678 & 39.6 & 2 \\
\hline 5 & Taiwan & Н/д & 68.4 & 3 & 47 & Greece & 22301 & 39.5 & 3 \\
\hline 6 & France & 29819 & 68.2 & 3 & 48 & China & 7418 & 39.5 & 2 \\
\hline 7 & UK & 32863 & 67.8 & 3 & 49 & Tunis & 8258 & 39.2 & 2 \\
\hline 8 & Switzerland & 39412 & 67.3 & 3 & 50 & $\begin{array}{l}\text { Dominican } \\
\text { Republic }^{* \star \star}\end{array}$ & 8651 & 39.0 & 2 \\
\hline 9 & Netherlands & 37112 & 66.1 & 3 & 51 & Argentina & 15501 & 38.9 & 2 \\
\hline 10 & Iceland $^{* *}$ & 33516 & 66.0 & 3 & 52 & Costa Rica & 10735 & 38.0 & 2 \\
\hline 11 & Finland & 32027 & 65.7 & 3 & 53 & Macedonia & 9451 & 38.0 & 2 \\
\hline 12 & Singapore & 53591 & 65.1 & 3 & 54 & Mexico & 12814 & 37.9 & 2 \\
\hline 13 & Norway & 46982 & 65.1 & 3 & 55 & Jordan $^{* \star *}$ & 5268 & 36.2 & 2 \\
\hline 14 & Belgium & 33127 & 64.1 & 3 & 56 & Serbia & 9830 & 35.6 & 2 \\
\hline 15 & Germany & 34603 & 63.1 & 3 & 57 & Botswana & 13021 & 35.4 & 1 \\
\hline 16 & Chile & 15251 & 62.5 & 2 & 58 & Namibia & 5986 & 34.5 & 2 \\
\hline 17 & Ireland & 36145 & 61.6 & 3 & 59 & Panama & 13766 & 34.4 & 2 \\
\hline 18 & Austria & 36139 & 61.5 & 3 & 60 & Thailand & 7635 & 34.2 & 2 \\
\hline 19 & Israel & 26720 & 58.0 & 3 & 61 & Russia & 14821 & 33.6 & 2 \\
\hline 20 & Estonia & 18129 & 57.8 & 2 & 62 & Nigeria & 2237 & 33.3 & 1 \\
\hline 21 & Slovenia & 24967 & 52.8 & 3 & 63 & $\begin{array}{l}\text { Trinidad and } \\
\text { Tobago }\end{array}$ & 22142 & 32.6 & 2 \\
\hline 22 & South Korea & 27541 & 52.2 & 3 & 64 & Morocco $^{* * *}$ & 4373 & 32.4 & 2 \\
\hline 23 & Saudi Arabia** & 21430 & 51.1 & 1 & 65 & Jamaica* $^{*}$ & Н/д & 32.3 & 2 \\
\hline 24 & Poland & 18087 & 50.5 & 2 & 66 & Salvador & 6032 & 31.9 & 2 \\
\hline 25 & Colombia & 8860 & 50.0 & 2 & 67 & Bolivia** & 4503 & 31.6 & 1 \\
\hline 26 & Lithuania & 16877 & 49.8 & 2 & 68 & Algeria & 7643 & 31.3 & 1 \\
\hline 27 & Turkey & 13468 & \begin{tabular}{|l|l|}
49.7 &
\end{tabular} & 2 & 69 & Egypt & 5547 & 30.8 & 1 \\
\hline 28 & UAE $^{*}$ & 42293 & 48.7 & 3 & 70 & $\begin{array}{l}\text { Bosnia and } \\
\text { Herzegovina }\end{array}$ & 7607 & 30.4 & 2 \\
\hline 29 & Latvia & 13773 & 48.7 & 2 & 71 & Ecuador & 7655 & 29.7 & 2 \\
\hline 30 & Spain & 26917 & 47.8 & 3 & 72 & Brazil & 10279 & 29.6 & 2 \\
\hline 31 & Japan & 30660 & 47.7 & 3 & 73 & Zambia & 1431 & 28.9 & 1 \\
\hline 32 & Hong Kong ${ }^{\star *}$ & 44640 & 47.0 & 3 & 74 & Angola & 5227 & 28.0 & 1 \\
\hline 33 & Czech Republic ${ }^{*}$ & 24011 & 46.9 & 3 & 75 & Venezuela* ${ }^{*}$ & 11258 & 28.0 & 1 \\
\hline 34 & Slovakia & 20757 & 46.8 & 3 & 76 & Iran & 10462 & 27.3 & 1 \\
\hline 35 & Portugal & 21304 & 46.4 & 3 & 77 & Ghana & 1652 & 26.7 & 1 \\
\hline 36 & Romania & 10905 & 45.7 & 2 & 78 & Pakistan & 2424 & 24.2 & 1 \\
\hline 37 & Uruguay & 13315 & 45.1 & 2 & 79 & Guatemala $^{*}$ & 4351 & 22.9 & 1 \\
\hline 38 & Hungary & 17295 & 43.3 & 2 & 80 & Malawi & 789 & 21.3 & 1 \\
\hline 39 & Malaysia & 14174 & 43.3 & 2 & 81 & Ethiopia & 979 & 21.1 & 1 \\
\hline 40 & Lebanon $^{* * *}$ & 12900 & 42.6 & 2 & 82 & Uganda & 1188 & 20.1 & 1 \\
\hline 41 & Peru & 9037 & 42.4 & 2 & 83 & Bangladesh $^{*}$ & 1569 & 18.6 & 1 \\
\hline 42 & Croatia & 15954 & 41.5 & 2 & & & & & \\
\hline \multicolumn{10}{|c|}{$\begin{array}{l}\text { Notes: GDP means per capita GDP (PPP) for } 2011 \text { in } 2005 \text { prices, according to World Bank data; development level }=\text { the country’s development level } \\
\text { calculated using the WEF methodology: } 1 \text { - factor-driven economies, } 2 \text { - efficiency-driven economies, and } 3 \text { - innovation-driven economies. } \\
{ }^{*} \text { Data for } 2011 \text {; }{ }^{* *} \text { Data for 2010; } * * * \text { Data for } 2009 \text {. } \\
\text { Source: [Szerb, Trumbull, 2015]. }\end{array}$} \\
\hline
\end{tabular}


Table 7. GEDI deviations from the main trend for each of the four groups of countries

\begin{tabular}{|l|r|r|l|r|r|}
\hline \multicolumn{1}{|c|}{ Country } & GEDI & $\begin{array}{r}\text { GEDI } \\
\text { deviation } \\
\text { from trend }\end{array}$ & \multicolumn{1}{|c|}{ Country } & $\begin{array}{r}\text { GEDI } \\
\text { GEDI } \\
\text { from trend }\end{array}$ \\
\hline Czech Republic & 46.9 & -5.0 & Bosnia and Herzegovina & 30.4 & -3.4 \\
\hline Estonia & 57.8 & 12.4 & Croatia & 41.5 & -1.5 \\
\hline Hungary & 43.3 & -1.2 & Macedonia & 38.0 & 2.2 \\
\hline Latvia & 48.7 & 8.2 & Montenegro & 40.7 & 3.8 \\
\hline Lithuania & 49.8 & 5.8 & Serbia & 35.6 & -0.6 \\
\hline Poland & 50.5 & 5.2 & Slovenia & 52.8 & -0.1 \\
\hline Romania & 45.7 & 8.3 & Average for former European market socialist economies & 39.8 & \\
\hline Russia & 33.6 & -8.1 & Average for transitioning European economies & 44.1 & 0.1 \\
\hline Slovakia & 46.8 & -1.6 & Average for non-transitioning European economies & 61.2 & 1.6 \\
\hline $\begin{array}{l}\text { Average for former European } \\
\text { planned socialist economies }\end{array}$ & 47.0 & 2.7 & Average for efficiency-driven European economies & 39.0 & 1.5 \\
\hline Source: [Szerb, Trumbull, 2015]. & & & 2.1 \\
\hline
\end{tabular}

All countries were further clustered and divided into four groups (two study groups and two control ones) [Szerb, Trumbull, 2015]: the former planned socialist economies and former market socialist economies on the one hand, and the non-transitional efficiency-driven countries, on the other (since the vast majority of post-socialist countries are efficiency-driven in terms of their economic development level). It resulted, firstly, in the discovery of a statistically significant gap between the average level of entrepreneurial development in post-socialist and other European countries. While in the first group the GEDI index was close to 44, countries that did not go through a systemic transformation phase usually had a value at around 61, i.e., a $28 \%$ gap in favor of non-transitional economies (Table 7). Secondly, in terms of the development of entrepreneurship, post-social countries turned out to be closer to the group of efficiency-driven economies. According to [Szerb, Trumbull, 2015], this means that the level of economic development provides a satisfactory explanation for the disparities in entrepreneurial development [Szerb, Trumbull, 2015, p. 9-10].

However, the results obtained by grouping specific indicators (Table 8) refute the previous conclusion. Not only do post-socialist countries show weaker performance than other European nations in terms of expected and perceived cultural support of entrepreneurship, there is also significant heterogeneity among post-socialist countries. The differences are apparent both in individual (the first six groups of indicators) and institutional values, and were noted even between countries with quite similar per capita GDP figures. For example, Slovakia nearly exceeds Hungary by two-fold regarding the individual "Networking" indicator and the institutional "Venture capital" indicators; Estonia and Poland show a significant (1.5-2 times) gap in six of the 14 indicator groups; finally, two former Yugoslav republics, Macedonia and Montenegro, have quite different values in the two groups of individual indicators and the two groups of institutional ones.

An analysis of the dynamics of post-socialist economies' indicator values also produced a contradictory picture (Table 9). Data presented in [Szerb, Trumbull, 2015] indicates that the gap between these and other European countries' (i.e., those which have never been socialist) GEDI values is gradually narrowing. At the same time, during the period under consideration Slovenia's integral indicator value noticeably dropped (the WEF includes this nation in the group of innovation-driven economies); relevant figures for Latvia, the Czech Republic, and Macedonia have dropped insignificantly - by $2 \%$, just as they have in Russia. Only Hungary and Romania demonstrated statistically significant growth, while in Bosnia and Herzegovina and Croatia the growth was within the margin of error. However, it would be hard to call Hungary a liberal market economy. The overall picture displays rather stagnant or even negative processes in the "old" capitalist countries after the 2007 economic recession and the subsequent structural reforms in European countries. Their GEDI dynamics compared with the slow, positive dynamics of post-socialist economies casts the latter in a favorable light.

In other words, a comparison of post-socialist economies with one other is very difficult because it reveals quite different, occasionally even contradictory, dynamics of entrepreneurial development, while comparing them with other European countries might be deceptive. On the one hand, this might have to do with the base effect and recovery growth; on the other, with the weak growth of private businesses during the transition to a new socioeconomic and societal order by established market economies.

The value of the Entrepreneurial Aspirations Index, which is comprised of several indicators of the adult economically active population's willingness to establish a new venture during the period under consideration, has dropped or remained at least unchanged in six countries, while it grew only in three: 
Table 8. Distribution of European post-socialist countries by 14 groups of entrepreneurial development indicators, compared with other nations

\begin{tabular}{|c|c|c|c|c|c|c|c|c|c|c|c|c|c|c|c|c|c|}
\hline Country & 1 & 2 & 3 & 4 & 5 & 6 & 7 & 8 & 9 & 10 & 11 & 12 & 13 & 14 & $\begin{array}{c}\text { Average for } \\
\text { institutional } \\
\text { factors }\end{array}$ & $\begin{array}{c}\text { Average } \\
\text { for specific } \\
\text { factors }\end{array}$ & GEDI \\
\hline Czech Republic & 0.34 & 0.53 & 0.21 & 0.49 & 0.34 & 0.45 & 0.56 & 0.24 & 0.52 & 0.68 & 0.79 & 0.89 & 1.00 & 0.53 & 0.68 & 0.64 & 46.9 \\
\hline Estonia & 0.38 & 0.59 & 0.48 & 0.78 & 0.54 & 0.60 & 0.75 & 0.51 & 0.65 & 0.63 & 0.62 & 0.73 & 0.90 & 0.38 & 0.70 & 0.68 & 57.8 \\
\hline Hungary & 0.18 & 0.52 & 0.28 & 0.46 & 0.49 & 0.50 & 0.66 & 0.41 & 0.46 & 0.46 & 0.44 & 0.72 & 0.81 & 0.36 & 0.64 & 0.58 & 43.3 \\
\hline Latvia & 0.26 & 0.58 & 0.30 & 0.60 & 0.42 & 0.52 & 0.53 & 0.57 & 0.54 & 0.55 & 0.37 & 1.00 & 0.78 & 0.42 & 0.60 & 0.66 & 48.7 \\
\hline \begin{tabular}{|l|} 
Lithuania \\
\end{tabular} & 0.27 & 0.59 & 0.37 & \begin{tabular}{|l|}
0.55 \\
\end{tabular} & 0.47 & 0.53 & 0.53 & 0.83 & 0.43 & 0.40 & 0.43 & 0.94 & 0.75 & 0.46 & 0.65 & 0.65 & 49.8 \\
\hline \begin{tabular}{|l|} 
Poland \\
\end{tabular} & 0.38 & 0.82 & 0.38 & \begin{tabular}{|l|}
0.71 \\
\end{tabular} & 0.55 & 0.32 & 0.42 & 0.33 & 0.54 & 0.82 & 0.41 & 0.67 & 0.86 & 0.52 & 0.69 & 0.62 & 50.5 \\
\hline \begin{tabular}{|l|} 
Romania \\
\end{tabular} & 0.38 & 0.50 & 0.29 & \begin{tabular}{|l|}
0.37 \\
\end{tabular} & 0.45 & 0.45 & 0.43 & 0.43 & 0.50 & 0.44 & 0.42 & 0.88 & 0.81 & 0.43 & 0.54 & 0.68 & 45.7 \\
\hline Russia & 0.44 & 0.46 & 0.29 & 0.49 & 0.26 & 0.44 & 0.31 & 0.83 & 0.31 & 0.27 & 0.36 & 0.49 & 0.08 & 0.33 & 0.60 & 0.49 & 33.6 \\
\hline \begin{tabular}{|l|} 
Slovakia \\
\end{tabular} & 0.21 & 0.60 & 0.46 & \begin{tabular}{|l|}
0.91 \\
\end{tabular} & 0.41 & 0.46 & 0.52 & 0.31 & 0.40 & 0.50 & 0.43 & 0.59 & 0.87 & 0.81 & 0.64 & 0.66 & 46.8 \\
\hline \begin{tabular}{|l} 
Bosnia and \\
Herzegovina
\end{tabular} & 0.15 & 0.40 & 0.11 & 0.49 & 0.47 & 0.20 & 0.43 & 0.24 & 0.41 & 0.23 & 0.26 & 0.44 & 0.47 & 0.41 & 0.48 & 0.54 & 30.4 \\
\hline \begin{tabular}{|l|} 
Croatia \\
\end{tabular} & 0.18 & 0.54 & 0.28 & \begin{tabular}{|l|}
0.48 \\
\end{tabular} & 0.36 & 0.39 & 0.58 & 0.31 & 0.49 & 0.35 & 0.48 & 0.64 & 0.83 & 0.54 & 0.57 & 0.64 & 41.5 \\
\hline \begin{tabular}{|l|} 
Macedonia \\
\end{tabular} & 0.23 & 0.45 & 0.19 & \begin{tabular}{|l|}
0.49 \\
\end{tabular} & 0.42 & 0.36 & 0.39 & 0.37 & 0.46 & 0.36 & 0.36 & 0.46 & 0.70 & 0.43 & 0.50 & 0.65 & 38.0 \\
\hline Montenegro & 0.22 & 0.72 & 0.20 & \begin{tabular}{|l|}
0.66 \\
\end{tabular} & 0.44 & 0.43 & 0.29 & 0.33 & 0.32 & 0.35 & 0.66 & 0.46 & 0.86 & 0.43 & 0.52 & 0.67 & 40.7 \\
\hline \begin{tabular}{|l|} 
Serbia \\
\end{tabular} & 0.37 & 0.73 & 0.25 & \begin{tabular}{|l|}
0.61 \\
\end{tabular} & 0.37 & 0.33 & 0.29 & 0.23 & 0.35 & 0.29 & 0.57 & 0.35 & 0.24 & 0.34 & 0.48 & 0.59 & 35.6 \\
\hline \begin{tabular}{|l|} 
Slovenia \\
\end{tabular} & 0.16 & 1.00 & 0.51 & \begin{tabular}{|l|}
0.75 \\
\end{tabular} & 0.55 & 0.66 & 1.00 & 0.60 & 0.53 & 0.61 & 0.71 & 0.63 & 0.77 & 0.44 & 0.70 & 0.70 & 52.8 \\
\hline $\begin{array}{l}\text { Average for former } \\
\text { European planned } \\
\text { socialist economies }\end{array}$ & 0.32 & 0.58 & 0.34 & \begin{tabular}{|l|}
0.60 \\
\end{tabular} & 0.44 & 0.47 & 0.52 & 0.50 & 0.48 & 0.53 & 0.47 & \begin{tabular}{|l|}
0.77 \\
\end{tabular} & 0.76 & 0.47 & 0.64 & 0.63 & 47.0 \\
\hline \begin{tabular}{|l|} 
Average for former \\
European market \\
socialist economies
\end{tabular} & 0.22 & 0.64 & 0.26 & \begin{tabular}{|l|l}
0.58 \\
\end{tabular} & 0.44 & 0.40 & 0.50 & 0.35 & 0.43 & 0.37 & 0.51 & 0.50 & 0.65 & 0.43 & 0.54 & 0.63 & 39.8 \\
\hline \begin{tabular}{|l} 
Average for \\
European post- \\
socialist countries
\end{tabular} & 0.28 & 0.60 & 0.31 & \begin{tabular}{|l|}
0.59 \\
\end{tabular} & 0.44 & 0.44 & 0.51 & 0.44 & 0.46 & 0.46 & 0.49 & 0.66 & 0.72 & 0.46 & 0.60 & 0.63 & 44.1 \\
\hline \begin{tabular}{|l} 
Average for other \\
European countries
\end{tabular} & 0.59 & 0.62 & 0.51 & 0.72 & 0.69 & 0.69 & 0.80 & 0.68 & 0.69 & 0.71 & 0.71 & 0.51 & 0.69 & 0.66 & 0.82 & 0.65 & 61.2 \\
\hline \begin{tabular}{|l|} 
Average for \\
efficiency-driven \\
European economies
\end{tabular} & 0.59 & 0.50 & 0.46 & 0.46 & 0.47 & 0.46 & 0.33 & 0.35 & 0.45 & 0.49 & 0.35 & 0.42 & 0.35 & 0.37 & 0.58 & 0.59 & 39.0 \\
\hline
\end{tabular}

Note: 1. Perceived opportunities (ATT); 2. Initial skills (ATT); 3. Perceived risk (ATT); 4. Networking (ATT); 5. Cultural support (ATT); 6. Early-stage opportunity-driven entrepreneurship (ABT); 7. Technology sector (ABT); 8. Quality of human resources (ABT); 9. Competition (ABT); 10. Product innovations (ASP); 11. Process innovations (ASP); 12. High growth rate (ASP); 13. Internationalization (ASP); 14. Venture capital (ASP).

GEDI - GEDI ranking; ATT — attitudes; ABT — abilities; ASP — aspirations.

Source: [Szerb, Trumbull, 2015].

Hungary, Romania, and Macedonia. In our opinion, it is precisely the level of entrepreneurial aspirations that most accurately reflects people's perceptions of their own abilities and the opportunities for successful entrepreneurial activity. In the GEDI methodology, this indicator is measured on the basis of the overall TEA without talking into account the share of necessity-driven entrepreneurship. If the latter would be taken into account, the conditions of entrepreneurial activity would be estimated less positively even in countries where entrepreneurial aspirations have improved.

Thus, significant differences between post-socialist countries are apparent both in the level and the rate of the development of entrepreneurship. Neither similar economic development levels nor a "common past" can explain the full extent of their disparity. Hence, new theoretical approaches to classifying the economies in question and their entrepreneurial ecosystems are needed.

\section{Paradigm concepts for classifying post-socialist countries' entrepreneurial ecosystems}

The institutional theory ${ }^{3}$ has sufficient conceptual resources for a detailed, substantiated classification of entrepreneurial ecosystems in post-social countries. Essentially, we mean that the theory differentiates between inclusive and extractive institutions and thus explains why some countries become successful and others do not [Acemoğlu, Robinson, 2012], as well as the concept of free versus limited access to

\footnotetext{
To provide a theoretical substantiation for the suggested approach, Zoltan Acs and co-authors [Acs et al., 2016, p. 530] employ three concepts: "national innovation system" [Nelson, 1993], "national comparative competitive advantage" [Porter, 1990], and "competition and entrepreneurship" [Kirzner, 1973] without even mentioning such concepts as "varieties of capitalism" [Hall, Soskice, 2001], "inclusive and extractive institutions" [Acemoğlu, Robinson, 2012], or the "access orders" theory [North et al., 2009].
} 
Table 9. Dynamics of the GEDI and three sub-indices by country, in 2006-2009 and 2010-2012

\begin{tabular}{|c|c|c|c|c|c|c|c|c|c|c|c|c|}
\hline \multirow{2}{*}{ Country } & $\begin{array}{c}2006- \\
2009\end{array}$ & $\begin{array}{c}2010- \\
2012 \\
\end{array}$ & \begin{tabular}{c|}
$2006-$ \\
2009
\end{tabular} & $\begin{array}{c}2010- \\
2012 \\
\end{array}$ & $\begin{array}{c}2006- \\
2009\end{array}$ & $\begin{array}{c}2010- \\
2012\end{array}$ & $\begin{array}{c}2006- \\
2009\end{array}$ & $\begin{array}{c}2010- \\
2012\end{array}$ & \multicolumn{4}{|c|}{$\begin{array}{l}\text { Growth from 2006-2009 } \\
\text { to } 2010-2012\end{array}$} \\
\hline & \multicolumn{2}{|c|}{ GEDI } & \multicolumn{2}{|c|}{ ATT } & \multicolumn{2}{|c|}{$\mathrm{ABT}$} & \multicolumn{2}{|c|}{ ASP } & GEDI & ATT & ABT & ASP \\
\hline Czech Republic & 51.0 & 50.2 & 42.4 & 42.8 & 43.1 & 42.8 & 67.4 & 64.9 & -0.8 & 0.4 & -0.3 & -2.5 \\
\hline Hungary & 37.4 & 46.0 & 41.1 & 42.1 & 40.6 & 48.7 & 30.4 & 47.1 & 8.6 & 1.0 & 8.1 & 16.7 \\
\hline Latvia & 49.6 & 47.5 & 45.7 & 44.3 & 52.6 & 47.6 & 50.6 & 50.6 & -2.2 & -1.4 & -5.0 & -0.1 \\
\hline Romania & 40.3 & 42.3 & 33.4 & 36.9 & 42.2 & 41.5 & 45.2 & 48.3 & 2.0 & 3.5 & -0.7 & 3.1 \\
\hline Russia & 34.6 & 32.6 & 27.1 & 31.2 & 43.3 & 38.4 & 33.4 & 28.1 & -2.0 & 4.1 & -4.9 & -5.3 \\
\hline Bosnia and Herzegovina & 30.3 & 30.5 & 31.5 & 31.2 & 25.0 & 28.5 & 34.2 & 32.0 & 0.3 & -0.3 & 3.4 & -2.2 \\
\hline Croatia & 43.3 & 43.9 & 44.8 & 38.5 & 34.9 & 44.1 & 50.3 & 49.1 & 0.6 & -6.3 & 9.2 & -1.2 \\
\hline Macedonia & 38.9 & 38.7 & 39.7 & 36.0 & 36.1 & 36.7 & 40.8 & 43.5 & -0.1 & -3.7 & 0.6 & 2.6 \\
\hline Slovenia & 58.0 & 53.9 & 58.6 & 52.5 & 58.4 & 55.6 & 57.1 & 53.6 & -4.1 & -6.2 & -2.8 & -3.4 \\
\hline $\begin{array}{l}\text { Average for former } \\
\text { European planned } \\
\text { socialist economies }\end{array}$ & 42.6 & 43.7 & 37.9 & 39.5 & 44.4 & 43.8 & 45.4 & 47.8 & 1.1 & 1.5 & -0.6 & 2.4 \\
\hline $\begin{array}{l}\text { Average for former } \\
\text { European market } \\
\text { socialist economies }\end{array}$ & 42.6 & 42.2 & 42.5 & 39.5 & 39.8 & 41.8 & 45.6 & 45.2 & -0.5 & -3.0 & 2.0 & -0.4 \\
\hline $\begin{array}{l}\text { Average for European } \\
\text { post-socialist countries }\end{array}$ & 42.6 & 42.8 & 40.5 & 39.5 & 41.8 & 42.7 & 45.5 & 46.4 & 0.2 & -1.0 & 0.9 & 0.9 \\
\hline $\begin{array}{l}\text { Average for other } \\
\text { European countries }\end{array}$ & 63.0 & 61.2 & 62.5 & 60.6 & 64.8 & 63.2 & 61.6 & 59.8 & -1.8 & -1.9 & -1.6 & -1.8 \\
\hline $\begin{array}{l}\text { Average for efficiency- } \\
\text { driven European } \\
\text { economies }\end{array}$ & 39.5 & 40.9 & 41.6 & 45.5 & 38.5 & 38.7 & 38.2 & 38.7 & 1.4 & 3.8 & 0.2 & 0.4 \\
\hline
\end{tabular}

the market [North et al., 2009]. These theories allow one to explain why in different socioeconomic contexts, even given comparable economic development levels, different entrepreneurial ecosystems may emerge - based on productive, non-productive, and destructive entrepreneurship as well as their various combinations [Baumol, 1990].

According to Daron Acemoğlu and James Robinson, in countries with market economies and established democracies, the "organic" inclusive institutions play a leading role, i.e. those that support the reproduction of the socioeconomic system [Acemoğlu, Robinson, 2012]. On the contrary, if a market economy is weak and civil society is poorly developed (as is the case in some of the transitioning post-socialist countries, especially those outside the legal and institutional orbit of the EU), so-called "extractive" political and/ or economic institutions could emerge. Their specific feature is a concentration of political authority in the hands of a weak government incapable of providing basic social security to its citizens [Acemoğlu, Robinson, 2012]. At this point, Acemoğlu and Robinson's concept merges with the limited access concept proposed by North et al. [North et al., 2009]. Extractive economic institutions, which do not guarantee property rights or limit the power of monopolies, lead to the emergence of limited market access for actors not integrated into the government bureaucracy.

Various combinations of inclusive and extractive institutions lead to different configurations of entrepreneurial ecosystems (see Table 10). In post-socialist countries, these systems are either based on inclusive institutions (e.g., some of the CEE countries that are new members of the EU), or are hybrid ones, i.e., those combining formally inclusive political institutions with de facto extractive economic ones (such as CIS countries and some of the former Yugoslav republics).

Societal and institutional differences between the two extremes on the "open access - limited access" scale determine the framework conditions for the development of national entrepreneurial ecosystems. The less productive systems are also affected by economic factors that accompany systemic transformation and create a kind of vicious circle where the primitive structure of the economy leaves no opportunity for the emergence of innovative entrepreneurship. Such negative factors include the following:

- Low labor productivity inherited from the previous socioeconomic system: after twenty-five years since the beginning of reforms in most of these countries, this indicator's value ranges between $30 \%$ and $70 \%$ of advanced European economies' level. As a consequence, domestic products turn out to be more expensive than imported ones, so trade and services (such as catering, construction, repairs, etc.) become a natural niche for private entrepreneurship;

- Low effective demand from the population, especially at the initial stage of systemic transformation (the first half of the 1990s) prompts entrepreneurs to go into the informal sector of the economy to increase their revenues, with the government and "predatory businesses" pushing them further in the same direction [Feige, 1997; Williams, 2008; Scase, 2000; et al]. 
Table 10. Prevailing entrepreneurial forms amid the dominance of various types of economic and political institutions

\begin{tabular}{|c|c|c|c|}
\hline \multirow{2}{*}{\multicolumn{2}{|c|}{ Institutions }} & \multicolumn{2}{|r|}{ Political } \\
\hline & & Extractive & Inclusive \\
\hline \multirow[t]{2}{*}{ Economic } & Extractive & $\begin{array}{l}\text { Destructive entrepreneurship } \\
\text { prevails (some African and } \\
\text { Asian countries and regions } \\
\text { controlled by terrorist groups) }\end{array}$ & $\begin{array}{l}\text { Productive entrepreneurship serves the political } \\
\text { interests of the government and non-productive } \\
\text { entrepreneurs affiliated with it (some of the post- } \\
\text { socialist countries with de jure property rights de jure } \\
\text { in place, but with a de facto monopolized economy) }\end{array}$ \\
\hline & Inclusive & $\begin{array}{l}\text { Productive entrepreneurship } \\
\text { serves political interests of the } \\
\text { government (Greece, Chile } \\
\text { during the junta rule, etc.) }\end{array}$ & $\begin{array}{l}\text { Productive entrepreneurship defines the ecosystem } \\
\text { (the older and some of the new EU member states) }\end{array}$ \\
\hline
\end{tabular}

\section{Conclusions}

Our analysis confirms the previously suggested hypothesis that entrepreneurship ecosystems in postsocialist countries remain very heterogeneous due to a wide range of factors, among which a common past is an important but by no means only determinant. The level of these countries' economic development measured using the WEF criteria does not fully explain the disparities in the quality of their entrepreneurial environments and activities. Economies with similar GDP per capita development levels show different levels of entrepreneurial activities and vice versa. Over the course of systemic transformation, the post-socialist economies have demonstrated not only different rates, but different directions ("different systemic transformations"). As a result, some created conditions for the emergence of a favorable business climate based on predominantly productive entrepreneurship, while others put in place limited access orders with predominantly non-productive entrepreneurship.

The existing approaches to measuring the quality of entrepreneurial activities using quantitative indicators support the above conclusion, but also have obvious limitations. The NES concept and the related GEDI index [Acs et al., 2013, 2014, 2016] do allow one, under certain circumstances, to rank countries, but do not provide criteria for classifying them. These criteria have to be borrowed from other theories. An attempt to link the different access orders with the specific context and quality of entrepreneurial activities [Chepurenko, 2015] seems to be more promising in terms of classifying post-socialist countries, but it suffers from a lack of empirical data. Accordingly, the number of clusters in effect matches the number of clustering subjects.

Combining approaches to classifying transitional (hybrid, unstable) socioeconomic systems on the basis of the new concepts offered by institutional theory and the empirical analysis of framework conditions for development of entrepreneurship would help one more fully understand the specific features of entrepreneurial development in post-socialist countries. The variety of entrepreneurial paths, frameworks, ecosystems, and measures implemented to support small and medium private businesses should take into account the relevant individual characteristics of each specific post-socialist country, while any general recommendations tend to be less than effective.

The paper was written using materials obtained over the course of the project "Effects of specific regional budget and taxation policies on entrepreneurial potential" implemented within the scope of the HSE Basic Research Programme in 2016.

\section{References}

Acemoğlu D., Robinson J. (2012) Why Nations Fail: The Origins of Power, Prosperity, and Poverty, Danvers, MA: Crown Publishers.

Acs Z., Szerb L. (2011) The Global Entrepreneurship and Development Index 2011, Cheltenham: Edward Elgar Publishing.

Acs Z.J., Audretsch D.B., Lehmann E.E. (2013) The Knowledge Spillover Theory of Entrepreneurship. Small Business Economics, vol. 41, no 4, pp. 757-774. DOI: 10.1007/s11187-013-9505-9.

Acs Z.J., Audretsch D.B., Lehmann E.E., Licht G. (2016) National Systems of Entrepreneurship. Small Business Economics, vol.16, no 4, pp. 527-535. DOI: 10.1007/s11187-016-9705-1.

Acs Z.J., Autio E., Szerb L. (2014) National systems of entrepreneurship: Measurement issues and policy implications. Research Policy, vol. 43, no 3, pp. 476-494. DOI:10.1016/j.respol.2013.08.016.

Aidis R. (2005a) Entrepreneurship in transition countries: A review (UCL SSEES Working Papers 61), London: University College London.

Aidis R. (2005b) Institutional barriers to small- and medium-sized enterprise operations in transition countries. Small Business Economics, vol. 25, no 4, pp. 305-318. 
Aidis R., Estrin S., Mickiewicz T. (2010) Institutions, finance and the level of development: The impact on entrepreneurship in transition. Review of Economics and Institutions, vol. 1, no 1, Article 3. DOI: 10.5202/ rei.vli1.3. Available at: http://www.rei.unipg.it/rei/article/view/3, accessed 12.06.2017.

Amoros J., Bosma N. (2013) Global Entrepreneurship Monitor 2013 Global Report: Fifteen Years of Assessing Entrepreneurship Across the Globe, London: Global Entrepreneurship Research Association.

Autio E., Levie J. (2015) Management of Entrepreneurial Ecosystems, London: Imperial College Business School (mimeo).

Batjargal B. (2006) The dynamics of entrepreneurs' networks in a transitioning economy: The case of Russia. Entrepreneurship \& Regional Development, vol. 18, no 4, pp. 305-320.

Baumol W. (1990) Entrepreneurship: Productive, unproductive, and destructive. Journal of Political Economy, vol. 98, no 5, pp. 893-921.

Black B.S., Kraakman R., Tarassova A. (2000) Russian privatization and corporate governance: What went wrong? Stanford Law Review, vol. 52, no 6, pp. 1731-1808.

Blanchard O. (1998) The economics of post-communist transition, Oxford: Clarendon Press.

Bosma N., Wennekers S., Amoros J. (2012) Global Entrepreneurship Monitor 2011 Extended Global Report: Entrepreneurs and Entrepreneurial Employees Across the Globe, London: Global Entrepreneurship Research Association.

Boycko M., Shleifer A., Vishny R.W. (1997) Privatizing Russia, vol. 1, Cambridge, MA: MIT Press.

Chepurenko A. (2015) Entrepreneurial activity under 'transition'. Context, Process and Gender in Entrepreneurship (eds. R. Blackburn, U. Hytti, F. Welter), Cheltenham: Edward Elgar, pp. 6-22.

Chepurenko A.Y., Gabelko M., Obraztsova O. (2012) Early-stage entrepreneurial activity: An explanatory model for cross-country comparisons (HSE Working Paper WP1/2011/04), Moscow: HSE Publishing.

Chepurenko A. (2008) The 'Oligarhks' in Russian mass consciousness. Politics and the Ruling Group in Putin's Russia (ed. S. White), Basingstoke: Palgrave Macmillan, pp. 120-137.

Chilosi A. (2001) Entrepreneurship and transition. MOST: Economic Policy in Transitional Economies, vol. 11, no 4, pp. 327-357.

Cieslik J.A., van Stel A. (2012) Trends in entrepreneurial activity in Central and East European transition economies (Scales Research Reports H201202), Zoetermeer: EIM Business and Policy Research.

Commander S., Tolstopiatenko A. (1997) A model of the informal economy in transition economies (William Davidson Institute Working Paper no 22), Ann Arbor, MI: University of Michigan.

Dallago B. (1997) The economic system, transition and opportunities for entrepreneurship. Entrepreneurship and SMEs in Transition Economies, The Visegrad Conference, Paris: OECD, pp. 103-124.

Earle J., Sakova Z. (2000) Business start-ups or disguised unemployment? Evidence on the character of self employment from transition economies. Labour Economics, vol. 7, no 5, pp. 575-601.

Estrin S., Meyer K., Bytchova M. (2006) Entrepreneurship in transition economies. The Oxford Handbook of Entrepreneurship (eds. M. Casson, A. Basu, B. Yeung, N. Wadesdon), Oxford: Oxford University Press.

Estrin S., Mickiewicz T. (2010) Entrepreneurship in transition economies: The role of institutions and generational change. The dynamics of entrepreneurship: Evidence from the global entrepreneurship monitor data (ed. M. Minniti), Oxford: Oxford University Press, pp. 181-208.

Feige E. (1997) Underground activity and institutional change: Productive, protective, and predatory behaviour in transition economies. Transforming Post-Communist Political Economies (eds. J. Nelson, C. Tilly, L. Walkerm), Washington, D.C.: National Research Council, pp. 21-34.

Gros D., Steinherr A. (2004) Economic transition in Central and Eastern Europe: Planting the seeds, Cambridge: Cambridge University Press.

Hall P.A., Soskice D. (2001) Varieties of capitalism: The institutional foundations of comparative advantage, Oxford: Oxford University Press.

Hashi I., Krasniqi B. (2011) Entrepreneurship and SME Growth: Evidence from advanced and laggard transition economies, International Journal of Entrepreneurial Behaviour \& Research, vol. 17, no 5, pp. 456-487.

Hessels J., van Gelderen M., Thurik R. (2008) Entrepreneurial aspirations, motivations, and their drivers. Small Business Economics, vol. 31, no 3, pp. 323-339.

Johnson S., McMillan J., Woodruff C. (2000) Entrepreneurs and the ordering of institutional reform. Economics of Transition, vol. 8, no 1, pp. 1-36.

Kihlgren A. (2003) Small business in Russia - factors that slowed its development: An analysis. Communist and Post-Communist Studies, vol. 36, no 2, pp. 193-207.

Kirzner I.M. (1973) Competition and Entrepreneurship, Chicago; London: University of Chicago Press.

Kontovorich V. (1999) Has new business creation in Russia come to a halt? Journal of Business Venturing, vol. 14, no 5-6, pp. 451-460.

Kornai J. (1992) The Rise of the Private Sector, "The Socialist System", Princeton: Princeton University Press.

Kornai J. (2006) The great transformation of Central Eastern Europe. Economics of Transition, vol. 14, no 2, pp. 207-244.

Korosteleva J. (2014) Analytical Report on GEM in CEECs (GRINCOH Working Paper no 3.08.1), Brussels: European Commission. Available at: http://www.grincoh.eu/media/serie_3_knowledge_innovation_ technolog/grincoh_wp_3.08.1_korosteleva.pdf, accessed 15.04.2017.

Lafuente E., Vaillant Y. (2013) Age driven influence of role-models on entrepreneurship in a transition economy. Journal of Small Business and Enterprise Development, vol. 20, no 1, pp. 181-203.

Manolova T., Eunni R., Gyoshev B. (2008) Institutional environments for entrepreneurship: Evidence from emerging economies in Eastern Europe. Entrepreneurship Theory and Practice, vol. 32, no 1, pp. 203-218.

McMillan J., Woodruff C. (2002) The central role of entrepreneurs in transition economies. Journal of Economic Perspectives, vol. 16, no 3, pp. 153-170. 
Nelson R.R. (1993) National Innovation Systems: A Comparative Analysis, Oxford: Oxford University Press.

North D.C., Wallis J.J., Weingast B.R. (2009) Violence and social orders: A conceptual framework for interpreting recorded human history, Cambridge: Cambridge University Press.

Obraztsova O., Chepurenko A. (2010) Entrepreneurship and socio-economic development in cross-countries analysis. Strategic Entrepreneurship - The Promise for Future Entrepreneurship, Family Business and SME Research (eds. U. Fueglistaller, T. Volery, W. Weber), St. Gallen: KMU-HSG.

Ovaska T., Sobel R.S. (2005) Entrepreneurship in post-socialist economies. Journal of Private Enterprise, vol. 21, no 1 , pp. 8-28.

Puffer S., McCarthy D. (2001) Navigating the hostile maze: A framework for Russian entrepreneurship. The Academy of Management Executive, vol. 15, no 4, pp. 24-38.

Raiser M., Rousso A., Steves F. (2003) Trust in transition: Cross-country and firm evidence (EBRD Working Paper no 82), London: European Bank for Reconstruction and Development.

Rehn A., Taalas S. (2004) Znakomstva i svyazi (Acquaintances and connections): Blat, the Soviet Union, and mundane entrepreneurship. Entrepreneurship and Regional Development, vol. 16, no 3, pp. 235-250.

Reynolds P., Bosma N., Autio E., Hunt S., de Bono N., Servais I., Lopez-Garcia P., Chin N. (2005) Global Entrepreneurship Monitor: Data Collection Design and Implementation 1998-2003, Small Business Economics, vol. 24, no 3, pp. 205-231.

Rona-Tas A., Sagi M. (2005) Entrepreneurship and Self-Employment in Transition Economies. Entrepreneurship Research in the Sociology of Work (ed. L.A. Keister), vol. 15, Bingley: Emerald Publishing, pp. 279-310.

Sachs J.D. (1996) The transition at mid decade. American Economic Review, vol. 86, no 2, pp. 128-133.

Sauka A., Welter F. (2007) Productive, unproductive and destructive entrepreneurship in an advanced transition setting: The example of Latvian small enterprises. Empirical Entrepreneurship in Europe: New Perspectives (eds. M. Dowling, J. Schmude), Cheltenham, UK; Northampton, MA: Edward Elgar, pp. 87-105.

Scase R. (1997) The role of small businesses in the economic transformation of Eastern Europe: Real but relatively unimportant. International Small Business Journal, vol. 16, no 1, pp.113-121.

Scase R. (2000) Entrepreneurship and Proprietorship in Transition: Policy Implications for the Small-and Medium-size Enterprise Sector, Helsinki: United Nations University World Institute for Development Economics Research.

Scase R. (2003) Entrepreneurship and Proprietorship in Transition: Policy Implications for the SME Sector. Small and Medium Enterprises in Transitional Economies (eds. R. McIntyre, B. Dallago), London: Palgrave Macmillan, pp. 64-77.

Schillo S., Persault J. (2016) Entrepreneurial readiness in the context of national systems of entrepreneurship. Small Business Economics, vol. 46, no 4, pp. 619-637.

Shane S., Locke E., Collins C.J. (2003) Entrepreneurial motivation. Human Resource Management Review, vol. 13, no 2, pp. 257-280.

Smallbone D., Welter F. (2002) The distinctiveness of entrepreneurship in transition economies. Small Business Economics, vol. 16, no 4, pp. 249-262.

Spicer A., McDermott G. A., Kogut B. (2000) Entrepreneurship and privatization in Central Europe: The tenuous balance between destruction and creation. Academy of Management Review, vol. 25, no 3, pp. 630-649.

Szerb L., Trumbull W. (2015) Entrepreneurship and transition in the European transition countries. Is Transition Complete? Paper presented at the ERSA - European Regional Science Association Congress 2015, 25-28 August 2015, Lisbon, Portugal. DOI: 10.1002/jsc.2051.

van der Zwan P., Verheul I., Thurik R. (2011) The entrepreneurial ladder in transition and non-transition economies. Entrepreneurship Research Journal, vol. 1, no 2, pp. 1-20.

Volkov V. (2012) Silovoe predprinimatel'stvo, XXI vek: ekonomiko-sotsiologicheskii analiz [Strong entrepreneurship, XXI century: Economic and sociological analysis], Saint-Petersburgh: Publishing House of the European University in St. Petersburg.

WEF (2015) Leveraging Entrepreneurial Ambition and Innovation: A Global Perspective on Entrepreneurship, Competitiveness and Development, Davos: World Economic Forum. Available at: httpwww3.weforum. orgdocsWEFUSA_EntrepreneurialInnovation_Report.pdf, accessed 12.11.2016.

Welter F. (2005) Entrepreneurial Behaviour in Differing Environments. Local Heroes in the Global Village (eds. D.B. Audretsch, H. Grimm, C.W. Wessner), vol. 7, New York: Springer, pp. 93-112.

Welter F. (2011) Contextualizing entrepreneurship - conceptual challenges and ways forward. Entrepreneurship Theory and Practice, vol. 35, no 1, pp. 165-184.

Welter F., Kautonen T., Chepurenko A., Malieva E., Venesaar U. (2005) Trust environments and entrepreneurial behavior - exploratory evidence from Estonia, Germany and Russia. Journal of Enterprising Culture, vol. 12, no 4, pp. 327-349.

Welter F., Smallbone D. (2011a) Handbook of research on entrepreneurship policies in Central and Eastern Europe, Cheltenham: Edward Elgar.

Welter F., Smallbone D. (2011b) Institutional perspectives on entrepreneurial behavior in challenging environments. Journal of Small Business Management, vol. 49, no 1, pp. 107-125.

Williams C.C. (2008) Beyond necessity-driven versus opportunity-driven entrepreneurship: A study of informal entrepreneurs in England, Russia and Ukraine. International Journal of Entrepreneurship and Innovation, vol. 9, no 3, pp. 157-165. 